\title{
Mesoscale distribution of Oikopleura and Fritillaria (Appendicularia) in the Southern Gulf of Mexico: spatial segregation
}

Distribución a mesoescala de Oikopleura y Fritillaria (Appendicularia) en el sur del Golfo de México: segregación espacial

\section{César Flores-Coto ${ }^{1}$, Laura Sanvicente Añorve ${ }^{1}$, Felipe Vázquez-Gutiérrez ${ }^{1}$ and Marina Sánchez-Ramírez ${ }^{2}$}

\author{
${ }^{1}$ Universidad Nacional Autónoma de México, Instituto de Ciencias del Mar y Limnología, Apdo. Postal 70-305, 04510 \\ México D.F., México. cotoce@unam.mx \\ ${ }^{2}$ Instituto Politécnico Nacional, Escuela Nacional de Ciencias Biológicas, Laboratorio de Ecología, Col. Santo Tomas C.P. \\ 11340, Delegación Miguel Hidalgo, México, D.F. México
}

\begin{abstract}
Resumen.- Se analizó la existencia de segregación espacial a meso-escala en la distribución de Oikopleura y Fritillaria en el sur del Golfo de México. Se obtuvieron 97 muestras en la capa superficial de 50 m. Se midió la salinidad, temperatura y turbidez. A las densidades de Oikopleura y Fritillaria se aplicó el índice de Segregación Espacial 'D', y el nivel de significancia del resultado se probó con el método de Monte Carlo. El análisis de regresión de árbol (RT) se empleó para identificar los principales factores del medio ambiente que afectan la distribución de los géneros. El valor del índice de segregación fue de 0,67 y es considerado un valor alto. El análisis RT mostró a la turbidez como el principal factor influyendo en la distribución espacial de ambos géneros. Fritillaria fue encontrada en aguas turbias frente a los principales sistemas fluvio-lagunares y Oikopleura fue más abundante en aguas de surgencia sobre la plataforma de Yucatán. La distribución segregada de las apendicularias en el área de estudio parece fuertemente influenciada por las surgencias y corrientes asociadas y por la turbidez generada por la descarga de aguas continentales. Puede asumirse a las cadenas tróficas como un importante factor asociado. Se plantea la hipótesis que Oikopleura tiene una amplia dieta y una mayor eficiencia de filtración para grandes partículas (microfitoplancton) que le permiten explotar la producción en áreas de surgencia, en tanto las especies de Fritillaria no pueden. Esto permite explicar la segregación de estos géneros.
\end{abstract}

Palabras clave: Apendicularias, distribución a mesoescala, segregación espacial, turbidez

\begin{abstract}
The mesoscale spatial distribution of Oikopleura and Fritillaria in the southern Gulf of Mexico was analyzed to know the existence of segregation between them. Samples were taken on 97 stations in the $50 \mathrm{~m}$ upper layer. Temperature, salinity and turbidity were measured. The spatial segregation index ' $\mathrm{D}$ ' was applied to Oikopleura and Fritillaria densities and its significance was tested with Monte Carlo method. Regression Tree (RT) analyses were performed to identify the main environmental factors affecting the distribution of genera. The $D$ index value was 0.67 , considered as a high value. RT analyses showed the water turbidity was the main factor affecting the spatial distribution of both genera. Fritillaria was found in turbid waters off the main fluvio-lagoon systems and Oikopleura was most abundant in the up welling waters over Yucatan Shelf. The segregation distribution of appendicularians in the study area appear to be strongly influenced by up welling and associated currents, and turbidity generated by continental water discharges. It could be assumed that food webs are an important associated factor. We hypothesize that a broad diet and higher filtration efficiency for larger particles (microfitoplankton) allows Oikopleura species to exploit the production in up welling areas, whereas Fritillaria species can not. It may explain its spatial segregation of these genera.
\end{abstract}

Key words: Appendicularians, mesoscale distribution, spatial segregation, turbidity

\section{INTRODUCTION}

Appendicularians are among the most common zooplankton organisms and are widely distributed in all the oceans. In the pelagic environment, the ecological relevance of larvaceans is that they mobilize microbial production to higher trophic levels in marine food webs (Gorsky \& Fenaux 1998, Capitanio et al. 2005). These animals are major consumers of small phytoplankton, bacteria, as well as particulate and colloidal organic matter 
suspended in the water column (Flood et al. 1992). Appendicularians feed using a mucous structure called 'house' to filter and concentrate small particles ranging from colloids to large diatoms (Deibel 1998, Lambert 2005). The houses are rejected when the particles clog the filters (Esnal 1999). The houses in Oikopleuridae are discarded and renewed up to 16 times a day (Fenaux 1985). Living appendicularians and discarded houses are eaten by larger pelagic carnivores, including copepods, medusae, fish larvae, chaetognaths, and foraminifera (Lambert 2005, Purcell et al. 2005), as well as some fishes (Capitanio et al. 2005). Most species inhabit the $200 \mathrm{~m}$ surface layer however, permanent populations of appendicularians occur at meso- and bathypelagic zones indicating that a constant source of foods exists at those depths since larvaceans are incapable to store food energy (Lambert 2005).

One interesting aspect of the appendicularians biology, is the ability of some species to form large aggregations in seasons and areas where others species are very scarce or do not appear at all (Björnberg \& Forneris 1956a,b, Fenaux 1963, Alldredge 1982, Uye \& Ichino 1995). At a temporal scale, a seasonal segregation occurs among several species in a local station of the Mediterranean Sea (Fenaux 1963). At a spatially fine-scale Oikopleura and Fritillaria species co-occurred, however, at a spatial mesoscale where the areas are affected by the main circulation pattern, continental water discharges, mixing processes and oceanic gyres, some segregation among Oikopleuridae and Fritillaridae has been observed in Brazilian waters (Björnberg \& Forneris 1956a), California coast in USA (Alldredge 1982), or Rio de la Plata estuary, in Argentina (Capitanio \& Esnal 1997).

Particularly in coastal areas the appendicularians distribution is strongly affected by continental water discharges. Capitanio \& Esnal (1998) considered that appendicularians distribution off the Rio de la Plata estuary is influenced by turbidity front. Generally the fronts of the rivers are zones of high concentration of appendicularians (Dagg et al. 1996; Dagg \& Brown 2005).

In the Gulf of Mexico practically there are not studies on the distribution and abundance of appendicularian, except those of Flores-Coto (1974) in a small area around the La Blanqullia reef off Veracruz coasts and Tokioka \& Suarez-Caabro (1956) around Cuba Island.

There is little quantitative information on appendicularian abundance to analyze the co-occurrence or segregation of species at a spatial mesoscale.
Nevertheless, based on some studies (Fernández et al. 2004, Choe \& Deibel 2008) it could be assumed that food webs are an important factor in segregation distribution of Oikopleura and Fritillaria species in the southern Gulf of Mexico. Considering two different food webs in the study area we hypothesize that the size of available food plays a determining role in the segregation distribution of appendicularians.

\section{Material AND MEthods}

The study area is located in the southern Gulf of Mexico, between $18^{\circ}$ and $22^{\circ} \mathrm{N}$ and $18^{\circ}$ and $20^{\circ} \mathrm{W}$ (Fig. 1). The continental shelf in the study area is highly contrasting, as wide as $150 \mathrm{~km}$ in the northeastern region and no rivers; whereas in the southern region, is $50 \mathrm{~km}$ wide and with a strong influence of continental water discharges.

Water discharges from the Grijalva-Usumacinta River are $7-10 \times 10^{9} \mathrm{~m}^{3}$ month $^{-1}$ from July to November, and 1.6$4 \times 10^{9} \mathrm{~m}^{3} \mathrm{month}^{-1}$ from December to June (Czitrom et al. 1986). During the autumn-winter period, a down-coast current reaches the southern Bay of Campeche and meets an opposite west-current, generating an offshore transport (Zavala-Hidalgo et al. 2003). In the adjacent oceanic water the circulation is predominantly cyclonic (Salas et al. 1992).

Samples were collected mainly over the shelf on a grid of 97 oceanographic stations, at the end of summer from September 3 to October 8, 2003. Temperature and salinity data were measurement in situ with calibrate CTD sonde (Marc III/Woce). Turbidity (Nephelometric Turbidity Units) was measured on board with a nephelometer Hach Model 0220 (APHA 2005). Zooplankton was sampled from the upper $50 \mathrm{~m}$ of the water column using a conical net of $30 \mathrm{~cm}$ mouth diameter, $200 \mu \mathrm{m}$ mesh size, equipped with a flow meter (General Oceanic, model 2030R). Samples were fixed in $4 \%$ formaldehyde solution. All appendicularian were sorted and identified using mainly the Tokioka \& Suarez Caabro (1956) and Esnal (1999) studies.

Spatial segregation of Oikopleura and Fritillaria genera was tested by means of the dissimilarity index $D$ (White 1983): which ranges from 0 to 1 , indicating no segregation to perfect segregation respectively.

$$
D=\frac{1}{2} \sum_{i=1}^{97}\left|\frac{N_{1 i}}{N_{1}}-\frac{N_{2 i}}{N_{2}}\right|
$$




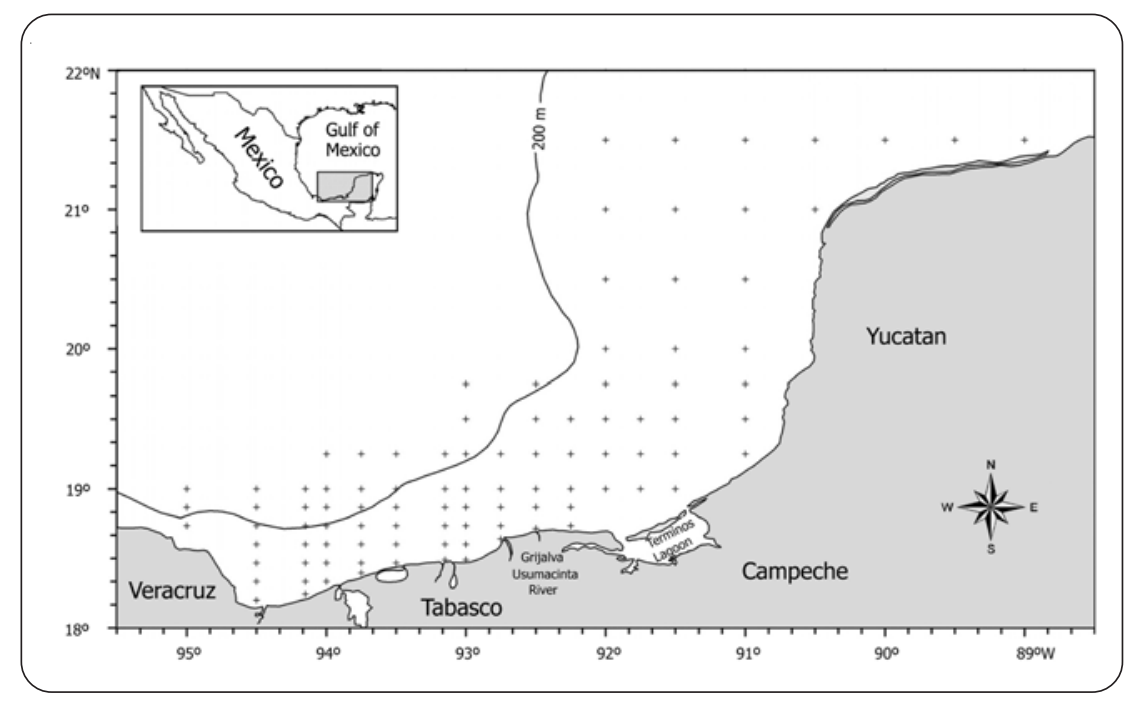

Figure 1. Study area and location of sampling stations indicated with ' + ' / Área de estudio y localización de estaciones de muestreo indicadas con ' $t$ '

Where:

$N_{1 i}=$ number of individuals of genus 1 at station $i$

$N_{2 i}=$ number of individuals of genus 2 at station $i$

$N_{1}=$ total number of individuals of genus 1

$N_{2}=$ total number of individuals of genus 2

The significance level of the $D$ statistic was evaluated by means of Monte Carlo simulations of the contingency table using the algorithm proposed by Roff \& Bentzen (1989). In this algorithm, a large number of randomizations (1000 in this study) of the original data set must be generated, subject to the constraint that the original row (Both genera) and column totals (sampling stations) remain equal to the original data matrix. A MATLAB program was developed for this purpose.

Regression Tree Analyses (Breiman et al. 1984, Urban 2002) were also employed to look for the environmental variables determining the spatial distribution of Oikopleura and Fritillaria genera in the southern Gulf of Mexico. SPLUS 2000 software was used. Data matrices included the temperature, the salinity, the turbidity, and the bottom depth as explanatory variables, and the log-transformed Fritillaria and Oikopleura densities as response variables. Regression Tree Analysis (RTA) explains the variation of a single numeric response variable using explanatory variables. RTA proceeds by a recursive binary splitting of the data into mutually exclusive groups, each of which has similar values of the response variable. Splits are generally chosen to minimize the total sum of squared residuals of the regression models fitted to data of resulting two nodes. The terminal nodes represent the groups of data formed by the tree (De'ath \& Fabricius 2000).

\section{RESUlts}

Temperature distribution as average of first $50 \mathrm{~m}$ of the water column, fluctuate between 27 to $30^{\circ} \mathrm{C}$ (Fig. 2A). Low temperatures were recorder in two zones, one in Tabasco neritic waters by the influence of continental water discharges of the Grijalva-Usumacinta River and the second one in the eastern portion of Yucatán shelf under the influence of Yucatán upwelling waters. Highest temperatures were recorded in coastal shallow waters around Terminos Lagoon. Average salinity of surface water down to $50 \mathrm{~m}$ fluctuated between 35.75 to 36.50 (Fig. 2B). Over the Campeche and Yucatan shelf salinity was very homogeneous and the largest variation occurred on the Tabasco shelf as consequence of the continental water discharges (Fig. 2B). Turbidity fluctuated between 0.2 and $0.8 \mathrm{NTU}$, with lower values ( 0.2 a $0.3 \mathrm{NTU}$ ) over the Campeche and Yucatán shelf, and higher values ( 0.4 a 0.8 NTU) on the Tabasco shelf (Fig. 2C).

Twenty species of appendicularians were identified in the study area during September 2003. The most abundant species were Oikopleura longicauda (70.30\%), O. fusiformis (13.62\%) and Fritillaria haplostoma (10.10\%). By genera, Oikopleura accounted for $85.93 \%$ of the total abundance, while Fritillaria 13.83\% (Table 1). Oikopleura (especially $O$. longicauda and $O$. fusiformis) was widely distributed in the study area, and was more abundant over 


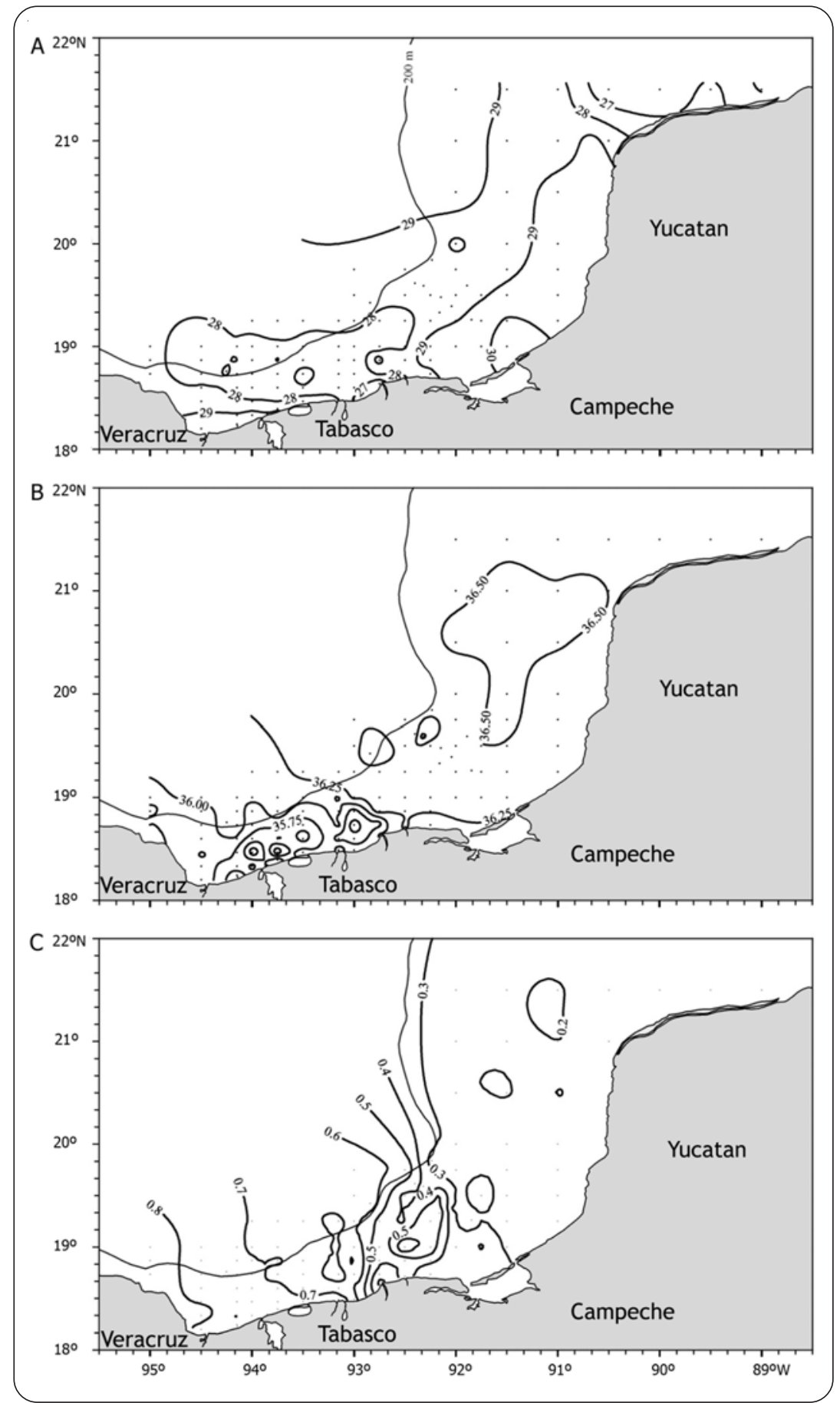

Figure 2. Isopleths of temperature (A), salinity (B) and turbidity (C), in the southern Gulf of Mexico, during September 2003 / Isopletas de temperatura (A), salinidad (B) y turbidez (C), en el sur del Golfo de México, durante septiembre de 2003

the wide Yucatán shelf (Fig. 3A). Fritillaria (especially F. haplostoma, F. borealis, and F. formica) was mainly found over Tabasco shelf, off of the main fluvial systems of the southern Gulf (Fig. 3B).

The spatial segregation index $(D)$ was 0.67 , estimated from Fritillaria and Oikopleura densities. None of the
1000 Monte Carlo simulations of the original data matrix produced a $D$ value higher than that obtained from the original data set (0.67). Thus, the null hypothesis of no significant variation between the observed $D$ value and those randomly generated was rejected $(P<0.001)$. 


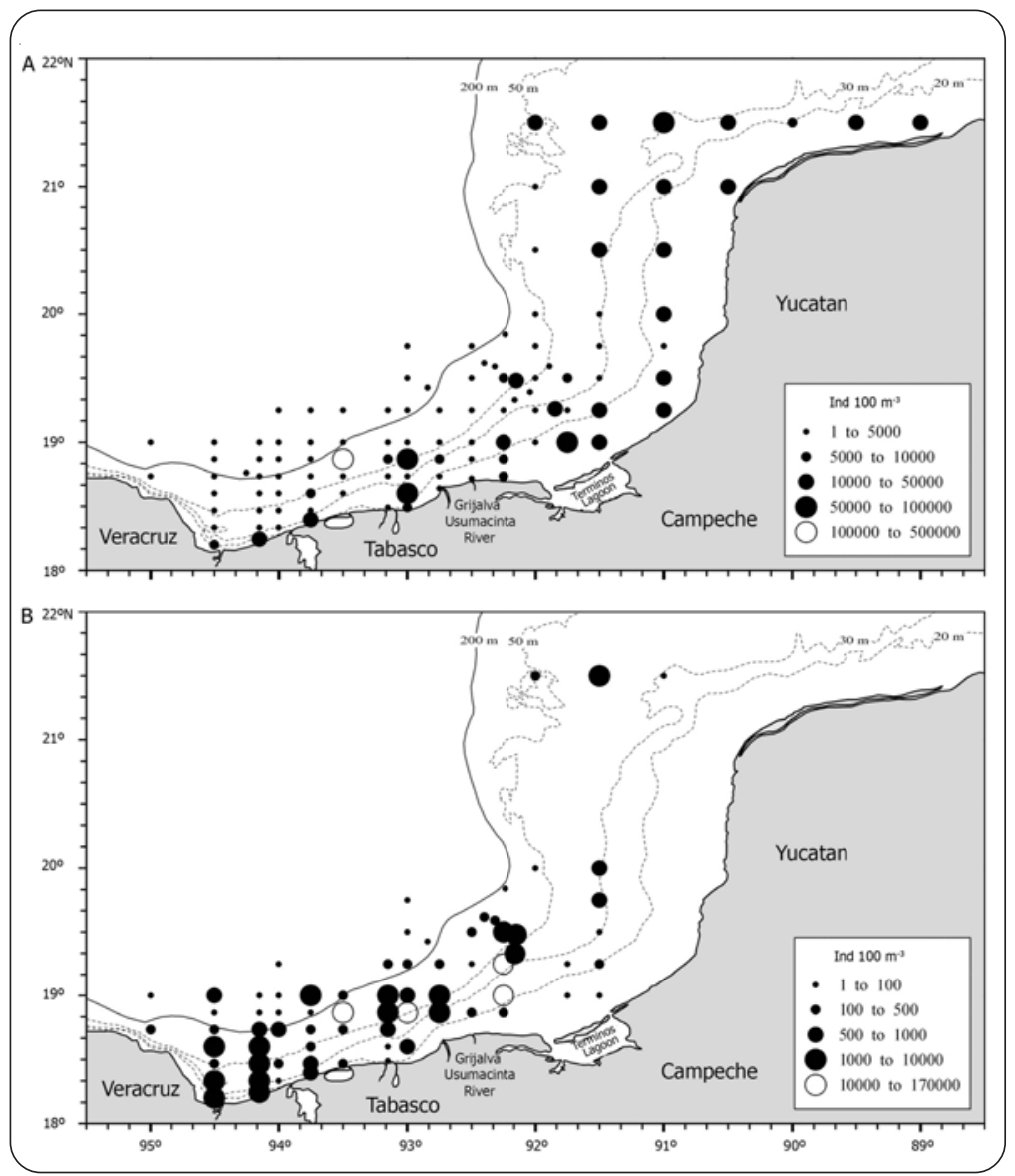

Figure 3. Distribution of Oikopleura (A) and Fritillaria (B) genera in the southern Gulf of Mexico, during September 2003 / Distribución de los géneros Oikopleura (A) y Fritillaria (B) en el sur del Golfo de México, durante septiembre de 2003
Table 1. Appendicularians collected in the southern Gulf of Mexico during September 2003. MA = Mean abundance (ind 100 $\mathrm{m}^{-3}$ ) and its SD = standard deviation, \%MA = percentage of species, and FO = Frequency of Occurrence (total stations 97) I Apendicularias colectadas en el sur del Golfo de México en septiembre 2003. MA = Media de la abundancia (ind $100 \mathrm{~m}^{-3}$ ) y su $\mathrm{DE}=$ desviación estándar, \%MA = porcentaje de las especies, y FO $=$ Frecuencia de ocurrencia (total de estaciones 97)

\begin{tabular}{lrrrr}
\hline Species & \multicolumn{1}{c}{ MA } & SD & $\% \mathrm{MA}$ & $\%$ FO \\
\hline Oikopleura longicauda & 8488.12 & 18293.2 & 70.759 & 95.88 \\
Oikopleura fusiformis & 1528.21 & 4050.3 & 12.740 & 70.10 \\
Oikopleura gracils & 22.12 & 85.5 & 0.184 & 15.46 \\
Oikopleura intermedia & 14.22 & 110.9 & 0.119 & 4.12 \\
Oikopleura dioca & 57.65 & 299.8 & 0.481 & 13.40 \\
Oikopleura rufescens & 135.06 & 636.7 & 1.126 & 28.87 \\
Oikopleura parva & 6.50 & 21.0 & 0.054 & 11.34 \\
Oikopleura cophocerca & 9.52 & 25.8 & 0.079 & 18.56 \\
Fritillaria haplostoma & 1243.38 & 4992.7 & 10.365 & 51.55 \\
Fritillaria formica & 91.48 & 440.8 & 0.763 & 28.87 \\
Fritillaria pellucida & 9.83 & 43.5 & 0.082 & 11.34 \\
Fritillaria borealis & 291.49 & 937.1 & 2.430 & 34.02 \\
Fritillaria magachile & 0.19 & 1.3 & 0.002 & 2.06 \\
Fritillaria fraudax & 64.83 & 539.3 & 0.540 & 15.46 \\
Fritillaria vemusta & 4.11 & 40.5 & 0.034 & 1.03 \\
Tectillaria fertilis & 1.42 & 6.9 & 0.012 & 5.15 \\
Appendicularia sicula & 26.34 & 248.6 & 0.220 & 4.12 \\
Pelagopleura oppressa & 0.60 & 3.6 & 0.005 & 3.09 \\
Stegosoma magnum & 0.49 & 3.4 & 0.004 & 2.06 \\
Folia gracilis & 0.24 & 2.4 & 0.002 & 1.03 \\
\hline
\end{tabular}

Regression Tree Analyses showed the turbidity as the major factor affecting the spatial distribution of Oikopleura and Fritillaria. Turbidity values lower than 0.49 NTU determine the highest densities of Oikopleura (Fig. 4A), whereas values higher than 0.356 NTU did the same for the Fritillaria species (Fig. 4B). At lower hierarchical levels of the trees, the temperature appears to have a secondary influence on the distribution of both genera, as well as the salinity and the bottom depth on Oikopleura and Fritillaria, respectively. In fact, RTA indicated that the highest densities of Oikopleura are found in low turbid and low temperature waters, whereas for Fritillaria the highest densities are found in highly turbid, shallow and high temperature waters (Fig. 4A, B).

\section{Discussion}

\section{SPATIAL SEgREgATION}

The spatial segregation index $D$ estimated from Fritillaria (mainly represented by F. haplostoma and F. borealis) and Oikopleura (mainly O. longicauda and O. fusiformis) 


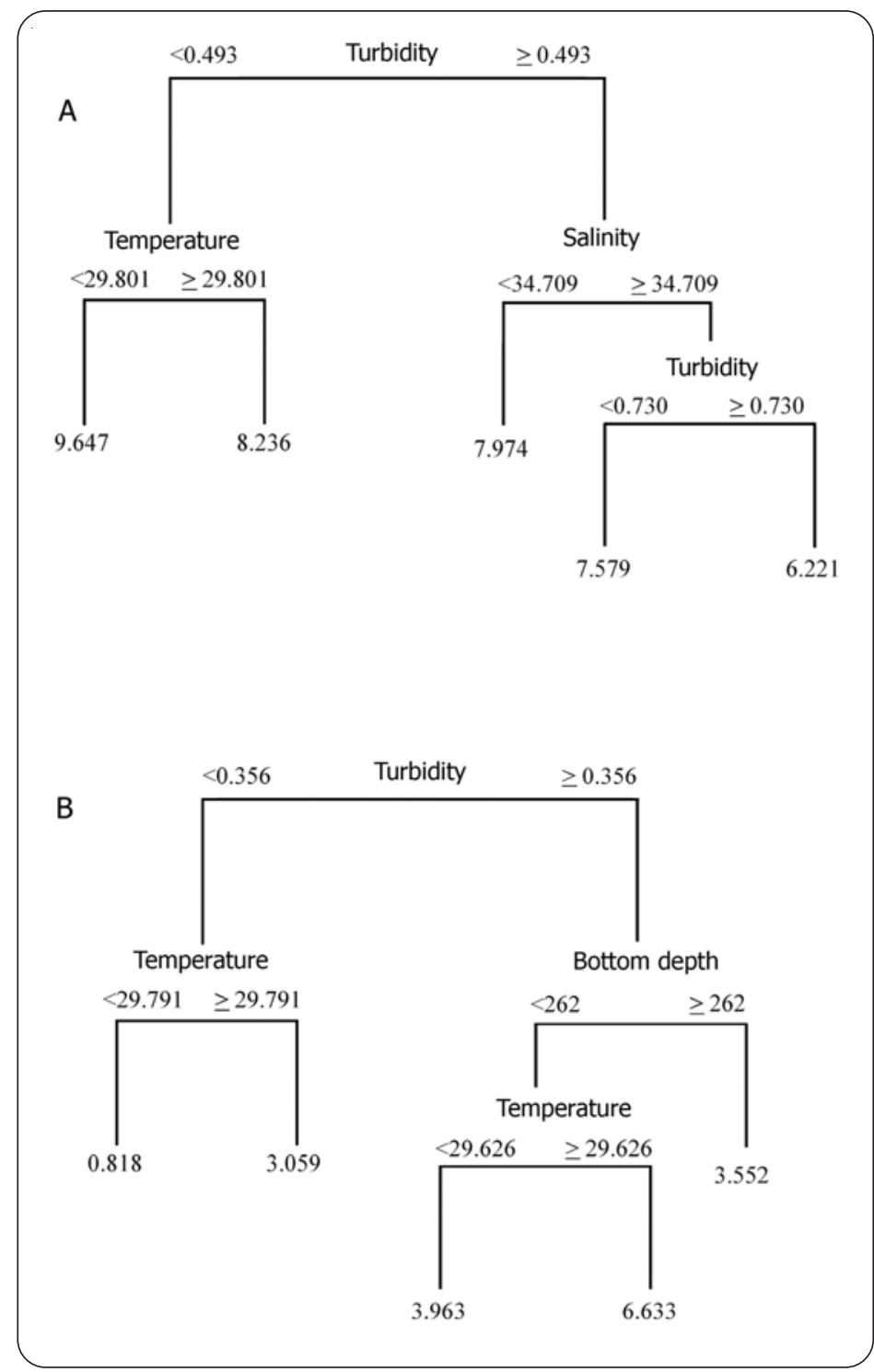

Figure 4. Regression Tree Analysis applied to the logtransformed A) Oikopleura, and B) Fritillaria density as response variable, and temperature, salinity, turbidity and bottom depth as explanatory variables. Values at the end of branches represent the appendicularian mean density

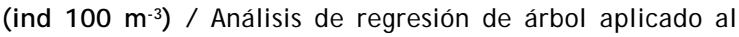
logaritmo de la densidad de A) Oikopleura, and B) Fritillaria como variable de respuesta y temperatura, salinidad, turbidez y profundidad, como variables explicativas. Los valores al final de la rama representan la densidad media de apendicularias (ind $100 \mathrm{~m}^{-3}$ )

densities was relatively high (0.67) and the Monte Carlo simulations proved its statistical significance. This result indicated that there is a clear mesoscale spatial segregation of both genera in the Southern Gulf of Mexico. The studies regarding to spatial segregation of appendicularians are scarce. Björnberg \& Forneris (1956a, b) described uneven distribution of appendicularians in Brazilian waters. Acuña (1994) and Fenaux et al. (1998) showed a vertical gradient of appendicularian species abundance in the epipelagic layer.
There are more documented examples about temporal segregation in nature rather than spatial. Fenaux (1963) in the French Mediterranean, recorded that Oikopleura species were dominant in summer and Fritillaria species were dominant in winter. López-Urrutia et al. (2005) also mentioned a seasonal segregation of appendicularins in some European seas, with oikopleurids dominating in summer and fritillarids in winter. Choe \& Deibel (2008) showed that the seasonal peak of abundance of tree species did not overlap on time. 


\section{DIFFERENT HYDRODYNAMIC AREAS}

The temperature, salinity and turbidity analysis showed that there are at least two areas with different hydrodynamic properties in the study zone; the eastern area, corresponding to the continental shelf of Yucatán and Campeche, and the western area, corresponding to the Tabasco shelf and adjacent oceanic area.

Yucatán-Campeche area, where oikopleurids were dominant and fritillarids almost absent, is characterized by no rivers discharges, low turbidity, relatively homogenous temperature and salinity. The hydrodynamic is determined by a branch of Yucatán Current, with high nutrient waters from the upwelling and associate flora (Hulburt \& Corwing 1972, Merino 1997, Zavala-Hidalgo et al. 2003). The western area where a high fritillarids density was recorded is characterized by low salinity and high turbidity waters, the hydrodynamic is determined by the continental water discharges and a cyclonic gyre in the oceanic adjacent area (Salas et al. 1992, Signoret et al. 2006), and associate flora (Licea \& Santoyo 1991, Licea et al. 2004). The characteristics of these two areas have been described in the study of the Campeche Bank by Besonov et al. (1971). Differences in oikopleurids and fritillarids abundances between these two areas must be related to the differences en hidrodynamics and associated food weebs.

The boundary between these two zones is variable through the seasons, nevertheless, the sediment on the shelf, which reflects long term phenomena, let us locate this on the continental shelf between the inlet of GrijalvaUsumacinta system and western inlet of Terminos Lagoon; with a carbonate sediments on the east and terrigenous sediments on the west of such boundary (Ayala-Castañares \& Gutiérrez Estrada 1990).

\section{TURBIDITY}

RT analyses revealed the turbidity as the main environmental factor affecting the spatial distribution of Oikopleura and Fritillaria genera (Fig. 3A, B). We consider that turbidity is mainly generated by the input of organic and inorganic matter coming from the continental water discharges. Capitanio \& Esnal (1997) considered that distribution limits of the recorded species in the Rio de la Plata estuary migth be influenced by turbidity front. Turbid water are also rich in nutrients and usually associated with phytoplankton blooms (Dagg 1995) which mean food availability for appendicularians.

\section{Temperature AND SALINITY}

Temperature and salinity had a small role on the distribution of both Oikopleura and Fritillaria genera (Fig. 3A, B). Studies (Acuña \& Anadón 1992, Acuña 1994) suggested that appendicularians are highly sensitive to water temperature and that species abundance exhibit an optimal unimodal response to temperature variations. However, different populations of the same species are adapted to different ranges depending on the localities (Fenaux et al. 1998). López-Urrutia et al. (2005) considered that temperature and in some degree salinity explain a considerable extent of seasonal and geographical distribution pattern, but also found a positive correlation between appendicularians abundance and chlorophyll concentration.

Choe \& Deibel (2008) base on vertical distribution found that some species are eurythermal and euryhaline (Fritillaria borealis) other mesothermal and mesohaline (Oikopleura labradorensis), and other stenothermal and stenohaline (Oikopleura vanhoffeni), and also referred a positive correlation between temporal variation of last species and chlorophyll concentration suggesting that physical parameters alone do not adequately explain the temporal distribution of appendicularians species.

Oikopleura longicauda is a eurythermic, warm water species even reaching the $60^{\circ}$ parallel (Aravena \& Palma 2002). In contrast, Fritillaria haplostoma is a more thermophilic form, mainly found in a temperature range of 21.1 to $28.2^{\circ} \mathrm{C}$ in a bay of Japan (Uye \& Ichino 1995). In accordance, highest densities of this species were here found at temperatures higher than $29^{\circ} \mathrm{C}$ (Fig. 3B). Temperature effects are more conspicuous in cold and temperate regions than in tropical ones (Fenaux et al. 1998). Results of this study showed that both temperature and salinity have minor effect on the distribution of both genera, as shown in the tree analysis.

\section{SIZES FOOD}

We assume that trophic chains are different in those two previously mentioned areas. In the upwelling waters on the Yucatan shelf, the primary production starts with large chains of diatoms, while in waters like those of Tabasco shelf generally start with nano and microphytoplankton (Ryther 1969, Urban et al. 1992). Besonov et al. (1971) indicated that in the eastern zone production of organic mater results only from primary producers and in the western zone organic matter is also added by the continental water discharges. 
Differences in the sizes food availability among these two areas must have an important role in the segregation of appendicularians. Oikopleurids species can retain besides of very small (0.2 to $6 \mu \mathrm{m}$ ) (Fernández et al. 2004), large particles which fritillarids can not. Oikopleura longicauda in particular can feed in a wide size spectrum of particles because it house lacks of incurrent filters which pre-filter the incoming water and remove large particles from the current, allowing feed in a wide spectrum of particles (Alldredge 1976) and exploits a variety of habitats, as observed in this study. In general Oikopleura species had a broad diet (Deibel 1998).

The size food for the appendicularias related with their distribution come to be more relevant every day. Choe \& Deibel (2008) related the seasonal abundance peaks of Fritillaria borealis in summer, Oikopleura labradorensis in fall and $O$. vanhoeffeni in spring with picoplankton, nanoplankton and large diatoms respectively as predominant preys species.

There are no comparative works on the types of primary producers between eastern (Yucatán) and westerns (Tabasco) areas. Nevertheless, Licea et al. (2004) found a pronounced difference between both areas, in the composition of the dominant species of dinoflagellates. Licea \& Santoyo (1991) indicated that primary production in the Tabasco shelf is mainly generated by nanoplankton and microplankton. On the other hand phytoplankton floras indicative of upwelling zones have been described on the Campeche Bank (Hulburt \& Corwing 1972). Consequently, over the Yucatán shelf with microplankton, characteristic of upwelling waters (Hulburt \& Corwing 1972, Cushing 1975), it must be an important food source for oikopleurids, but not for fritillarids. Knowledge on the diet of most of fritillarids is limited, but Brena et al. (2003) emphasized that cytological characters of the gut of fritillarids are different from those of the oikopleurids, indicating the possibility of different nutritional requirements. In the Artic polynyas during the spring upwelling Deibel et al. (2005) found a high production of oikopleurids. On the contrary, on the Tabasco shelf, primary production is mainly generated by nanoplankton and microplankton (Licea \& Santoyo 1991), and we assumed also picoplankton as result of microbial loop. Because the small size it must be an important food source for fritillarids and also for oikopleurids. Considering two different food webs we hypothesize that the size of available food plays a determining role in the segregation distribution of appendicularians.
In summary the mesoscale examination of Oikopleura and Fritillaria distribution indicate spatial segregation rather than a niche overlap. Aside of physical environmental features like, salinity, temperature, currents, gyres, continental waters discharges, turbidity, the causes of this spatial segregation obey to eco-physiological differences of oikopleurids and fritillarids: Oikopleura species had a broad diet, higher filtration efficiency for large particles than Fritillaria species. These ecological characteristics also explain the ecological success of Oikopleura in the Campeche Bank and other tropical areas.

\section{AcKnowledgments}

Authors express their gratitude to F. Zavala-García for his field and technical assistance, and to J. Schulz, from the Alfred Wegener Institute for Polar and Marine Research, for providing and traducing German literature. Especial thanks to the anonymous reviewers by the deep criticism and help to improve this paper. Material was obtained from the oceanographic cruise SGM8, Agreement PEMEXUNAM 412005877.

\section{LITERATURE CITED}

Acuña JL. 1994. Summer vertical distribution of appendicularians in the central Cantabrian Sea (Bay of Biscay). Marine Biology 74: 585-601.

Acuña JL \& R Anadón. 1992. Appendicularian assemblages in a shelf area and their relationship with temperature. Journal of Plankton Research 14: 1233-1250.

Alldredge AL. 1976. Field behavior and adaptive strategies of appendicularians (Chordata:Tunicata). Marine Biology 38: 29-39.

Alldredge AL. 1982. Aggregation of spawning appendicularians in surface windrows. Bulletin of Marine Science 32: 250-254.

APHA. 2005. Standard methods for the examination of water and wastewater, 1398 pp. American Public Health Association (APHA), American Water Works Association (AWWA) \& Water Environment Federation (WEF), Baltimore.

Aravena G \& S Palma. 2002. Taxonomic identification of appendicularians collected in the epipelagic waters off northern Chile (Tunicata, Appendicularia). Revista Chilena de Historia Natural 75: 307-325.

Ayala-Castañares A \& M Gutiérrez-Estrada. 1990. Morfología y sedimentos superficiales de la plataforma continental frente a Tabasco y Campeche, México. Anales del Instituto de Biología, Universidad Nacional Autónoma de México 17: 163-190.

Besonov N, O González \& A Elizarov. 1971. Resultados de las investigaciones Cubano-soviéticas en el Banco de 
Campeche. In: Coloquio sobre Investigaciones y Recursos del Mar Caribe y Regiones Adyacentes, UNESCO, Paris, pp. 318-323.

Bjorberg TKS \& L Forneris. 1956a. On the uneven distribution of the copelata of the Fernando Noronha area. Boletim do Instituto Oceanográfico, São Paulo 7: 105-111.

Bjorberg TKS \& L Forneris. 1956b. On the uneven distribution of the copelata of the Alcatrazes area. Boletim do Instituto Oceanográfico, São Paulo 7: 113-115.

Breiman L, JH Friedman, RA Olshen \& CJ Stone. 1984. Classification and regression trees, 368 pp. Chapman \& Hall, New York.

Brena C, F Cima \& P Buriguel. 2003. The highly specialized gut of Fritillariidae (Appendicularia: Tunicata). Marine Biology 143: 57-71.

Capitanio FL \& GB Esnal. 1997. Appendicularian distribution in the Rio de la Plata estuary and adjacent neritic areas. Neritica 11: 37-48.

Capitanio FL \& GB Esnal. 1998. Vertical distribution of maturity stages of Oikopleura dioica (Tunicata, Appendicularia) in the frontal system off Valdés Peninsula, Argentina. Bulletin of Marine Science 63: 531-539.

Capitanio FL, M Pájaro \& GB Esnal. 2005. Appendicularians: an important food supply for the Argentine anchovy Engraulis anchoita in coastal waters. Journal of Applied. Ichthyology 21: 414-419.

Choe N \& D Deibel. 2008. Temporal and vertical distribution of three appendicularian species (Tunicata) in Conception Bay, Newfoundland. Journal of Plankton Research 30(9): 969-979.

Cushing DH. 1975. Ecologia marina y pesquerías, 256 pp. Editorial Acribia, Zaragoza.

Czitrom SP, RF Ruiz, MA Alatorre \& AR Padilla. 1986. Preliminary study of a front in the Bay of Campeche, Mexico. In: Nihoul JCJ (ed). Marine interfaces ecohydrodynamics, pp. 301-311. Elsevier Oceanography Series 42, Amsterdan.

Dagg MJ. 1995. Copepod grazing and the fate of phytoplankton in the northern Gulf of Mexico. Continental Shelf Research 15: 1303-1317.

Dagg MJ \& SL Brown. 2005. The potential contribution of fecal pellets from larvaceans Oikopleura dioica to vertical flux of carbon in a river dominated coastal margin. In: Gorsky G, MJ Youngbluth \& D Deibel (eds). Response of marine ecosystems to global change, pp. 293-307. Contemporary Publishing International, Paris.

Dagg MJ, EP Green, BA McKee \& PB Orner. 1996. Biological removal of fine grained lithogenic particles from a large river plume. Journal of Marine Science 54: 149160.

De'ath G. 2002. Multivariate regression tree: a new technique for modelling species-environment relationships. Ecology 83: 1105-1117.
De'ath G \& KE Fabricius. 2002. Classification and regression trees: a powerful yet simple technique for ecological data analysis. Ecology 8(11): 3178-3192.

Deibel D. 1998. Feeding and metabolisms of appendicularians. In: Bone Q (ed). The biology of pelagic tunicates, pp. 139149. Oxford University Press, Great Britain.

Deibel D, PA Saunders, JL Acuña \& AB Bochdansky. 2005. The role of appendicularians tunicates in the biogenic carbon cycle of three Artic Polynyas. In: Gorsky G, MJ Youngbluth \& D Deibel (eds). Response of marine ecosystems to global change, pp. 327-356. Contemporary Publishing International, Paris.

Esnal GB. 1999. Appendicularia. In: Boltovskoy D (ed). South Atlantic zooplankton, pp. 1375-1399. Backhuys Publishers, Leiden.

Fenaux R. 1963. Ecologie et biologie des Appendicularies mediterraneens, 142 pp. Masson and Cie., Paris.

Fenaux R. 1985. Rhythm of secretion of Oikopleurid's houses. Bulletin of Marine Science 37: 498-503.

Fenaux R, Q Bone \& D Deibel. 1998. Appendicularian distribution and zoogeography. In: Bone Q (ed). The biology of pelagic tunicates, pp. 251-274. Oxford University Press, Oxford.

Fernández D, A López-Urrutia, A Fernández, JL Acuña \& RP Harris. 2004. Retention efficiency of 0.2 to $6 \mu \mathrm{m}$ particles by appendicularians Oikopleura dioica and Fritillaria borealis. Marine Ecology Progress Series 26: 89-101.

Flood P \& D Deibel. 1998. The Appendicularian house. In: Bone Q (ed). The biology of pelagic tunicates, pp. 105124. Oxford University Press, Oxford.

Flood P, D Deibel \& C Morris. 1992. Filtration of colloidal melanin from sea water by pelagic tunicates. Nature 355: 630-632.

Flores-Coto C. 1974. Contribución al conocimiento de las apendicularias del arrecife 'La Blanquilla' Veracruz, México, con descripción de una nueva especie. Anales del Centro de Ciencias del Mar y Limnología, Universidad Nacional Autónoma de México 1: 41-60.

Gorsky G \& R Fenaux. 1998. The role of Appendicularia in marine food webs. In: Bone Q (ed). The biology of pelagic tunicates, pp. 161-170. Oxford University Press, Oxford.

Hulburt EM \& N Corwin. 1972. A note on the phytoplankton distribution in the offshore water of the eastern and central Gulf of Mexico. Caribbean Journal of Science 12: 29-38.

Lambert G. 2005. Ecology and natural history of protochordates. Canadian Journal of Zoology 83: 34-50.

Licea S \& H Santoyo. 1991. Algunas características ecológicas del fitoplancton de la región central de la Bahia de Campeche. Anales del Instituto de Ciencias del Mar y Limnología, Universidad Nacional Autónoma de México 18: 157-167. 
Licea S, ME Zamudio, R Luna \& J Soto. 2004. Free-living dinoflagellates in the southern Gulf of Mexico: Report of data (1979-2002). Phycological Research: 419-428.

López-Urrutia A, X Irigoien, JLAcuña \& R Harris. 2003. In situ feeding physiology and grazing impact of the appendicularian community in temperate waters. Marine Ecology Progress Series 252: 125-141.

Merino M. 1997. Upwelling on the Yucatan shelf: Hydrographic evidence. Journal of Marine Systems 13: 101-121.

Purcell JE, MV Sturdevant \& CP Galt. 2005. A review of appendicularians as prey of invertebrate and fish predators. In: Gorsky G, MJ Youngbluth \& D Deibel (eds). Response of marine ecosystems to global change, pp. 359-435. Contemporary Publishing International, Paris.

Roff DA \& P Bentzen. 1989. The statistical analysis of mitochondrial DNA polymorphisms: $\chi^{2}$ and the problem of small samples. Molecular Biology and Evolution 6: 539545.

Ryther JH. 1969. Photosynthesis and fish production in the sea. Science 166: 72-76.

Salas-de-León D, MA Monreal-Gómez \& G ColungaEnriquez. 1992. Hidrografía y circulación geostrófica en el sur de la Bahía de Campeche. Geofísica Internacional 31: 315-323.

Signoret M, MA Monreal-Gómez, J Aldeco \& D Salas-de León. 2006. Hydrography, oxygen saturation, suspended particulate matter, and chlorophyll-a fluorescence in an oceanic region under fresh water influence. Estuarine, Coastal and Shelf Science 69: 153-164.

Tokioka T. 1955. General consideration on Japanese Appendicularian fauna. Publication of the Seto Marine Biological Laboratory 4: 251-261.

Tokioka T \& JA Suarez-Caabro. 1956. Apendicularias de los mares cubanos. Memorias de la Sociedad Cubana de Historia Natural Felipe Poey 3: 37-95.

Urban DL. 2002. Classification and regression trees. In: McCune B \& JM Grace (eds). Analysis of ecological communities, pp. 222-232. MjM Software Desing, Oregon.

Urban JL, CH McKenzie \& D Deibel. 1992. Seasonal differences in the content of Oikopleura vanhoeffeni and Calanus finmarchicus faecal pellets: Illustrations of zooplankton food web shifts in coastal Newfoundland waters. Marine Ecology Progress Series 84: 255-264.

Uye S \& S Ichino. 1995. Seasonal variations in abundance, size composition, biomass and production rate of Oikopleura dioica (Fol) (Tunicata: Appendicularia) in a temperate eutrophic inlet. Journal of the Experimental Marine Biology and Ecology 189: 1-11.

White MJ. 1983. The measurement of spatial segregation. The American Journal of Sociology 88: 1008-1018.

Zavala-Hidalgo J, SL Morey \& JJ O’Brien. 2003. Seasonal circulation on the western shelf of the Gulf of Mexico using a high-resolution numerical model. Journal of Geophysical Research 108 (C12): 1-19. <doi:10.1029/2003jc001879>

Recibido el 18 de febrero de 2010 y aceptado el 6 de abril de 2010 